\title{
Liikkuvien korkeakoulureformien domestikaatio Kirgisiassa
}

Opiskelin yliopistossa kasvatustieteiden opintojeni ohella arabian ja islamin tutkimusta. Sen sijaan että olisin perehtynyt arabian kielen koukeroihin, minua kiinnosti uskonnollisten oppilaitosten eli madrasojen merkitys yhteiskuntien rakentumisessa. Minua kiinnosti erityisesti se, miten oppineisuutta ja tietoa voidaan opettaa ja käyttää islamilaisen opin ja ideologian levittämiseen. Myöhemmin matkustin junalla Siperiaan oppimaan venäjän kieltä. Ja samalla pääsin tutustumaan siihen, miten koulutusta ja tiedettä on hyödynnetty sosialistisen ideologian liimana sekä Venäjän valtion ideologian rakentamisessa. Olikin varsin luontevaa tarttua haasteeseen ja muuttaa Keski-Aasiaan, jonne ovat kulkeutuneet niin arabien ja islamin kuin myös sosialismin ja Neuvostoliiton vaikutteet.

Keski-Aasia on alue, jolla on useita määritelmiä. Keski-Aasia on osa Aasiaa, ja se ulottuu lännessä Kaspianmerelle, idässä Kiinaan, etelässä Afganistaniin ja pohjoisessa Venäjälle. Keski-Aasia on ollut aina kohtauspaikka ihmisille, tavaroille ja ajatuksille Euroopan ja Aasian välillä. Yksi maailman historian merkittävimpiä kauppareittejä, Silkkitie, kulkee alueen läpi. Alueella ovat vuosisatojen aikana toimineet sekä mongolit, persialaiset, arabit, turkkilaiset että venäläiset. Aiemmin valloittaen, myöhemmin yhteistyön nimissä. Viimeisimpinä myös eurooppalaiset ja länsimaalaiset vaikutteet sekä ajatukset ovat rantautuneet Keski-Aasiaan. Nykyään Keski-Aasian maiksi määritellään Venäjän vallankumouksen jälkeen perustetut Neuvostotasavallat: Kazakstan, Uzbekistan, Turkmenistan, Tadžikistan ja Kirgisia.

Koulutuksella ja tieteellä on keskeinen merkitys tämän päivän yhteiskunnissa joissa tähdätään korkean teknologian ja tiedon hallintaan. Kansallisvaltioiden välisessä kilpailussa osaaminen ja korkeatasoinen koulutus korostuvat. Kansallisten pyrkimysten rinnalla on kuitenkin yhä enemmän globaaleja vaikutteita, ylikansallisia sopimuksia sekä liikkuvia korkeakoulureformeja, kuten Bolognan prosessi, laadunvarmistus- ja arviointireformeja sekä yksityisiä akkreditointiprosesseja. Tutkijoiden keskuudessa on kiistaton yhteisymmärrys siitä, että koulutuksen merkitys kansallisvaltioille ei ole vähenemässä, päinvastoin, korkeakoulutuksen kenttä on yhä riippuvaisempi globaaleista ilmiöistä. Vertaileva koulutustutkimus antaa työkaluja tarkastella tätä paikallisen ja globaalien välistä vuoropuhelua.

Miten tätä riippuvuussuhdetta tutkitaan ja tarkastellaan, riippuu pitkälti näkökulman valinnasta sekä epistemologisista lähtökodista. Esimerkiksi Columbia yliopiston vertailevan ja kansainvälisen koulutustutkimuksen professori Gita Steiner-Khamsin (2016; 2012) johdolla 
Policy borrowing and lending -tutkimuksissa huomio on keskittynyt siihen, miten samat koulutusreformit matkustavat ympäri maailmaa. Kontekstista, historiasta ja paikalliskulttuurista huolimatta samojen koulutuspoliittisten reformien avulla ratkotaan moninaisia paikallisia koulutuspoliittisia ongelmia.

Toisaalta taas Stanfordin yliopiston emeritusprofessori John Meyerin (1997) johdolla Maailman kulttuuriteoriassa (World Culture Theory) on korostettu lähentymisen merkitystä argumentoimalla, että globalisaation myötä koulutuksen mallit ja ratkaisut tulevat yhä samankaltaisemmiksi ympäri maailman. Maailman kulttuuriteorian näkökulmasta korkeakoulutuksen räjähdysmäinen kasvu kaikilla mantereilla on esimerkki globalisaation vaikutuksesta.

Tampereen yliopiston sosiologian professori Pertti Alasuutari $(2014 ; 2013)$ on puolestaan oman tutkimusryhmänsä kanssa tarkastellut paikallisten ja globaalien vaikutteiden välistä riippuvuussuhdetta domestikaatioteorian kautta. Domestikaatiotutkimuksessa käytetyn paikalliskamppailun käsitteen (domestic field battle) avulla koulutusreformien monimuotoisuus sekä globaalien ja paikallisten tavoitteiden välinen ristiriita tulevat näkyviksi. Domestikaatiotutkimuksissa ollaan tietoisia globaalien vaikutusten merkityksistä, vaikka samanaikaisesti sensitiivisyys paikallisille erityispiirteille tunnistetaan.

Keski-Aasiassa asuessani kiinnitin erityisesti huomiota siihen, kuinka samankaltaisia piirteitä on mahdollista löytää Kirgisian ja Suomen korkeakouluista, siitä huolimatta, että nämä maat eroavat toisistaan monessakin mielessä. Molemmissa maissa keskusteltiin laadunarviointireformeista, kaksiportaisesta tutkintorakenteesta, eurooppalaisesta korkeakoulujen opintopistejärjestelmästä sekä eurooppalaisesta Bolognan prosessista. Mitä Kirgisian korkeakoulutuksen kentällä oikein tapahtui rupesi kiinnostamaan minua yhä enemmän. Unohdin aiemmat suunnitelmani tutkia Venäjän korkeakoulumuutosta ja ryhdyinkin tarkastelemaan Kirgisian korkeakoulumuutosta.

Tutkimusta ohjaavaksi tehtäväksi tuli kysymys siitä, miten Kirgisian korkeakouludiskurssit ovat domestikoituneet kansainvälisissä korkeakoulureformeissa? Toisin sanoen, miten paikalliset tarpeet ja näkemykset vaikuttavat joko näkyvästi tai hiljaisesti kansainvälisten korkeakoulureformien paikallistumisessa.

Domestikaatiotutkimuksen näkökulmasta Kirgisia on Keski-Aasian maista erityisen kiinnostava. Keski-Aasian kontekstissa juuri Kirgisiassa länsimaalaiset vaikutteet ovat eniten näkyvillä. 2000-luvun alussa Kirgisiaa myös kutsuttiin käsitteellä "demokratian saari", jolla viitataan Kirgisian avautumiseen länsimaalaisille vaikutteille. Kirgisia oli ensimmäinen Keski-Aasian maa, joka hyväksyi modernin oikeudellisen sääntelykehyksen, hintojen vapauttamisen, teollisuuden yksityistämisen sekä avoimen poliittisen järjestelmän. Kirgisia oli myös ensimmäinen Keski-Aasian maa, joka liittyi Maailman kauppajärjestöön. Maa ei ole kuitenkaan välttynyt yhteiskunnalliselta turbulenssilta. Maan etelä- ja pohjoisosan välillä on etnisiä jännitteitä, jotka ovat aika ajoin purkautuneet levottomuuksiksi. Myös poliittiset vallanvaihdokset ovat aiheuttaneet levottomuuksia, joista viimeisimpinä syksyllä 2019 olleet levottomuudet entisen ja istuvan presidentin välillä.

Uudistus- ja länsimaalaisuusmielisyydestä huolimatta Kirgisia on maa, jolla on taakkanaan poliittisten jännitteiden lisäksi omia paikallisia haasteita. Kirgisia on väestöltään noin Suomen kokoinen valtio. Suomessa asuu noin 5,5 miljoonaa asukasta, kun taas Kirgisiassa on 6,2 miljoonaa ihmistä. Yhtenä ongelmana on ollut korkea työttömyysaste, joka kohdistuu erityisesti nuoriin. Vastauksena on ollut nuorten massamuutto työn perässä Venäjälle. Kansainvälisen siirtolaisuusjärjestön IOM:n (2019) mukaan vuosittain noin 500 000-800 000 Kirgisian kansalaista on muuttanut työn perässä muualle, pääsääntöisesti Venäjälle sekä 
Kazakstaniin. Neuvostoliiton hajottua nuorten tulevaisuuden näkymät muuttuivat valtiota johdattaneen ideologian kaatumisen myötä. Aivovuoto aiheutti myös omat ongelmansa yhteiskunnan kehitykselle, kun kaikki kynnelle kykenevät johtavat tieteentekijät muuttivat pois maasta. Muuttoliike aiheuttaa tänä päivänä myös merkittäviä sosiaalis- ja koulutuspoliittisia haasteita, koska esimerkiksi Unicefin (2019) mukaan 11 prosentilla lapsista, joko yksi tai molemmat vanhemmat ovat muuttaneet työn perässä ulkomaille.

Neuvostoliiton hajottua koulutukseen käytettävät valtion budjettivarat vähenivät, eikä maalla ollut kokemusta koulutusohjelmien suunnittelusta eikä uusista avoimista työmarkkinoista, olihan Kirgisian koulutussektori toiminut Moskovan ohjauksessa. Kirgisian hallitus hyväksyi nopeasti uusliberalistisen korkeakoulutusretoriikan ja laillisti yksityisten korkeakoulujen perustamisen sekä korosti demokratisoitumisen ja kilpailukyvyn luomisen tärkeyttä. Neuvostoliiton hajotessa Kirgisiassa oli 10 korkeakoulua ja reilussa kahdessakymmenessä vuodessa korkeakoulujen määrä oli noussut 53 yliopistoon. Korkeakouluopintojen avulla saatiin nuoret pysymään pois kaduilta vaeltamasta sekä myös estämään haitallisten ideologioiden leviämistä.

On arvioitu, että ääriliike Isisin riveihin on Keski-Aasiasta liittynyt noin 2000-4000 ihmistä, jotka pääsääntöisesti ovat nuoria. Näiden nuorten versojen elämään vaikuttaminen on vakavasti otettava asia, kuten eräs haastateltavani totesi:

Jos nuorilla ei ole mitään tekemistä, se on vaarallinen tilanne täällä Keski-Aasiassa islamin vaikutusvallan takia. Onneksi, meillä ei ollut niitä ongelmia, joita Tadžikistanissa on ollut sisällissodan kanssa. Ja Afganistan on aivan kulman takana. Meidän täytyy pitää huoli siitä, että nuoret pysyvät aktiivisina.

Ennen vuoden 1917 vallankumousta Kirgisiassa ei ollut yhtään korkeakoulua ja vain alle neljä prosenttia aikuisväestöstä osasi lukea. Kirgisiaan perustettiin koulutusjärjestelmä Neuvostoliiton aikana. Yhä edelleen Kirgisiassa ollaan lähes yksimielisiä siitä, että koulutus on ollut yksi niistä sektoreista, joilla maa hyötyi eniten Neuvostoliiton aikana. Neuvostojärjestelmän aikainen koulutus- ja tiedeusko ulottui aina Kirgisiaan asti. Vaikka Neuvostoliittolaista korkeakoulutusta on kritisoitu eliittiä suosivaksi, antoi se kuitenkin kirgisialaisille nuorille mahdollisuuksia päästä samalle viivalle muiden neuvostoliittolaisten nuorten kanssa. Näkökulmat kuitenkin eroavat siinä, mihin suuntaa korkeakoulutusta tulisi näinä päivinä rakentaa.

Vertailevan koulutustutkimuksen piirissä tutkijat ovat yhä enemmän kyseenalaistaneet näkemystä siitä, että koulutusmuutosta on mahdollista tarkastella lineaarisena jatkumona, jossa kehitys näyttäytyy tiettynä saavutuksena. Kirgisian korkeakoulusektorilla on nähtävissä, ettei post-sosialistinen koulutusmuutos ole ollut suoraviivainen prosessi, jossa neuvostoaikainen korkeakoulujärjestelmä korvataan länsimaalaisilla uudistuksilla. Päinvastoin. Esimerkiksi Iveta Silova (2018) haastaa tutkimuksillaan näkemyksen siitä, että post-sosialistiset maat väistämättömästi koulutusreformien ja uudistusten myötävaikutuksella muovautuisivat länsimaalaisten kaltaisiksi. Tällaisilla yksinkertaistuksilla ylenkatsotaan paikallisia erityispiirteitä, kulttuurillisia käsityksiä ja uskomuksia.

John Meyer on tutkimuksillaan pyrkinyt todistamaan, kuinka maailma lähentyy ja paikalliset käytänteet muuttuvat yhä enemmän globaaleja malleja mukaileviksi. Tutkimukseni kuitenkin osoittaa, että viimeaikaiset Kirgisian korkeakoulu-uudistukset ovat paikallisesti domestikoituja käsityksiä globaaleista liikkuvista korkeakoulureformeista. Vaikka Kirgisian 
viimeaikaiset korkeakoulupolitiikan vaikutteet sekä periaatteet tulevat globaaleista tavoitteista, korostuu paikallisen tason merkitys näitä tavoitteita tulkittaessa.

Maia Chankseliani Oxfordin yliopiston vertailevan ja kansainvälisen koulutustutkimuksen apulaisprofessori on tutkimuksissaan keskittynyt post-sosialistiseen koulutusmuutokseen. Chanskeliani (2018) on kiinnittänyt huomiota siihen, kuinka eurooppalaista korkeakoulupolitiikka ohjataan taloudellisista periaatteista käsin, sen sijaan, että huomio olisi kulttuurillisissa tai väestöllisissä kysymyksissä. Ongelmalliseksi tämä toimintamalli tulee eurooppalaisen korkeakoulupolitiikan liikkuvan luonteen johdosta. Nämä mallit ja reformit matkustavat maasta toiseen ja monissa tapauksissa paikallisen kulttuurin ja historian vaatimukset sekä erityispiirteet sivuutetaan.

Jokaisella yhteiskunnalla ja ryhmällä on omat näkemyksensä keskeisistä ja hyväksytyistä puhetavoista sekä yhteinen näkemys niistä puhetavoista, jotka on mahdollista haastaa sekä yhteisesti jaettu tietoisuus asioista, joita pidetään itsestäänselvyyksinä. Tarkastelemalla diskurssianalyyttisen luennan avulla on mahdollista tehdä näkyviksi ne uskomukset ja tiedon rakennelmat, jotka ohjaavat korkeakoulupoliittisten toimijoiden ajattelua. Tutkimukseni tavoitteenani ei ole ollut arvioida Kirgisian korkeakoulupoliittisten uudistusten onnistumista tai epäonnistumista, vaan olen pyrkinyt analysoimaan niitä puhetapoja, joiden avulla vaikutetaan korkeakoulupoliittiseen keskusteluun. Jossain tapauksissa ulkopuolisuus antaa paremmat eväät nähdä tarkasti sisälle.

Kirgisia ja Keski-Aasia yltää harvoin meillä Suomessa uutisten aiheeksi, mutta naapurissamme Venäjällä näiden maiden kehitys ja merkitys näyttäytyy jo toisessa valossa. Korkeakoulutuksella on mahdollista siirtää ajatuksia, tietoa sekä ideologioita. On kiistatonta, että koulutuksella ja korkeakoulutuksella on merkittävä rooli yhteiskuntien rakentumisessa ja Keski-Aasian maissa tämä muutosprosessi ei tapahdu ilman ulkopuolista apua. Neuvostoliiton hajottua Kirgisian koulutuspoliittiset reformit saivat syötteensä länsimaalaisilta toimijoilta, kansainvälisiltä organisaatioilta sekä globaaleista post-sosialistisista reformipaketeista (Gita Steiner-Khamsi 2012). Tänä päivänä, yli kahden vuosikymmen jälkeen voimme huomata, kuinka monet näistä reformeista ovat aiheuttaneet enemmän hämmennystä kuin hyötyä. Ei siis ihme, että myös korkeakoulutuksen puolella Kirgisia on tiivistämässä suhteitaan Venäjän kanssa. Onhan mailla yhteinen koulutushistoria koulutuksen suurvaltana.

Sari Eriksson

Sari Eriksson väitteli Helsingin yliopiston Kasvatustieteellisessä tiedekunnassa joulukuun 18. päivänä 2019 aiheesta: "Domestication of Travelling Reforms in Higher Education of Kyrgyzstan”. Vastaväittäjänä toimi tutkimusprofessori Taina Saarinen Jyväskylän yliopistosta ja kustoksena apulaisprofessori Janne Varjo. 


\section{Lähteet:}

Alasuutari, Pertti \& Qadir, Ali. (2014). Epistemic governance: an approach to the politics of policy making. European Journal of Cultural and Political Sociology, 1(1), 67-84.

Alasuutari, Pertti \& Qadir, Ali. (2013). Introduction. In Alasuutari, Pertti \& Qadir, Ali (Eds.), National Policy-making: Domestication of Global Trends. Routledge Advances in Sociology. 1-22.

Chankseliani, Maia \& Silova, Iveta (2018). Introduction. Reconfiguring Education Purposes, Policies and Practices during Post-socialist Transformations. In Silova, Iveta \& Chankseliani, Maia (eds.). Comparing Post-Socialist Transformations - purposes, policies, and practices in education. Symposium Books Ltd, 2018.

IOM. (2019). Migration and Development in Central Asia. https://iom.kg/en/?page_id=110

Meyer, John W., Boli, John, Thomas, George M. \& Ramirez Francisco O. (1997). World Society and Nation-State. American Journal of Sociology. Vol. 103, no. 1, 144-181.

Meyer, John W., Boli, John, Thomas, George M. \& Ramirez Francisco O. (1997). World Society and Nation-State. American Journal of Sociology. Vol. 103, no. 1, 144-181.

Silova, I. (2018). Comparing Post-socialist Transformations: dead ends, new pathways and unexpected openings. In Chankseliani Maia \& Silova Iveta (ed.) Comparing Post-Socialist Transformations purposes, poliies, and practices in education. Symposium Books, Southampton, 193-199.

Steiner-Khamsi, Gita (2016). Global Indicators and Local Problem Recognition: An Exploration into the Statistical Eradication of Teacher Shortage in the Post-Socialist Region. In Karen Mundy, Andy Green, Bob Lingard and Antoni Verger (ed). The Handbook of Global Education Policy. West Sussex: Wiley \& Sons, Ltd. 573-589.

Steiner-Khamsi, Gita. (2012). Understanding Policy Borrowing and Lending: Building Comparative Policy Studies. In G. Steiner-Khamsi and F. Waldow (eds.), Policy Borrowing and Lending in Education. World Yearbook of Education 2012. New York: Routledge. 3-18.

UNICEF (2019). Children of migrants. https://www.unicef.org/kyrgyzstan/children-migrants 